\title{
CORRECTION
}

\section{Correction to: Irradiation induces homing of donor endothelial progenitor cells in allogeneic hematopoietic stem cell transplantation}

\author{
Lingyu Zeng ${ }^{1,2} \cdot$ Shuang Ding ${ }^{2} \cdot{\text { Zhiling } \mathrm{Yan}^{2}}^{2}$ Chong Chen ${ }^{2} \cdot$ Wei Sang $^{2} \cdot$ Jiang Cao ${ }^{2} \cdot$ Hai Cheng $^{2} \cdot$ Kailin Xu $^{1,2}$
}

Published online: 29 November 2021

(c) Japanese Society of Hematology 2021

Correction to: Int J Hematol (2012) 95:189-197

https://doi.org/10.1007/s12185-011-1000-y

In the original publication of the article, figure 1 and its caption are published with errors. The corrected Fig. 1 and its caption are given in this correction.
Publisher's Note Springer Nature remains neutral with regard to jurisdictional claims in published maps and institutional affiliations.

The original article can be found online at https://doi.org/10.1007/ s12185-011-1000-y.

Kailin Xu

lihmd@163.com

1 Laboratory of Transplantation and Immunology, Xuzhou Medical College, Xuzhou, People's Republic of China

2 Department of Hematology, The Affiliated Hospital of Xuzhou Medical College, No. 99 West Huaihai Road, Xuzhou, Jiangsu, People's Republic of China 
Fig. 1 Variation of white blood cells, ECs and EPCs in circulation after TBI. The counters of white blood cells were lower than $0.5 \times 10^{9} 3$ days after irradiation, and continued to decline until the mice died (A). The numbers of ECs and EPCs were elevated after conditioning, reaching a maximum at day 3 or 5 (filled triangles and squares $P<0.05$ compared to control group) and were maintained for 3-5 days (B, C). Analysis of fluorescenceactivated cell sorting of EPCs and ECs in the normal group (D-F) and the irradiated group (G-I) at day 5 was conducted. Gate1 represents cells with CD45-, Gate2 represents cells with $\mathrm{CD} 45^{\text {low }}$. At day 5, EPCs $\left(\mathrm{CD} 45^{\text {low/-}} \mathrm{CD} 133^{+} \mathrm{CD} 31^{+}\right.$)

comprised $9.03 \%$ of the total $(\mathbf{H}, \mathbf{I})$ and ECs $\left(\mathrm{CD} 45^{-} \mathrm{CD} 133^{-} \mathrm{CD} 31^{+}\right)$constituted $74.26 \%$ of the total $(\mathbf{H})$ in the irradiated group
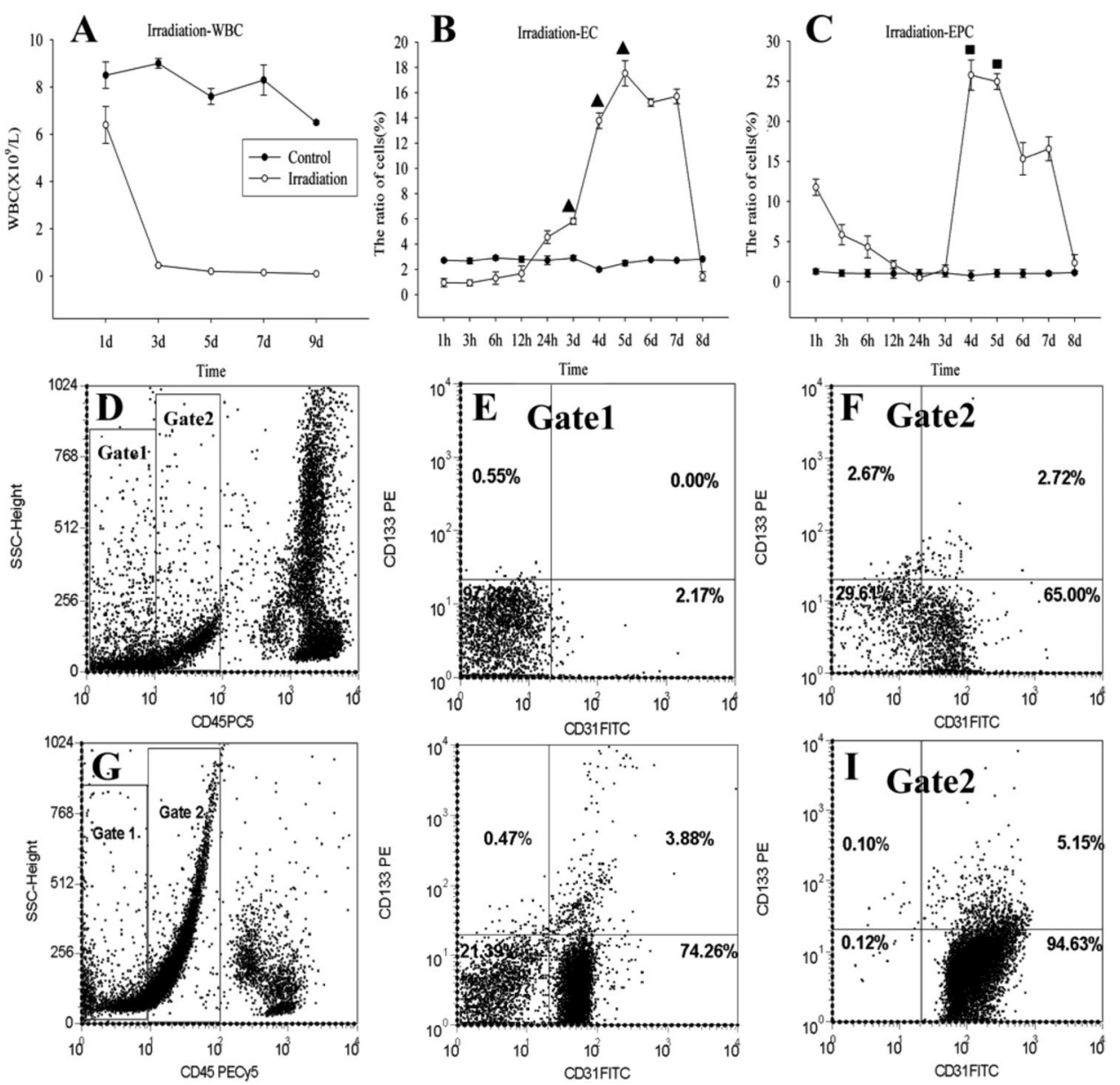